\title{
The Description of Implementation of Assisted Mobilization in Stroke Patients in Several Pontianak Hospitals in Predicting the Incidence of Pressure Ulcer
}

\author{
$1^{\text {st }}$ Sitti Syabariyah \\ Sekolah Tinggi Ilmu Kesehatan \\ 'Aisyiyah Bandung \\ Bandung, Indonesia \\ sittisyabariyah@gmail.com
}

\author{
$2^{\text {nd }}$ Nelly Juniarty \\ RSUD Sultan Syarif Moh Alkadrie \\ Hospital, Indonesia
}

\author{
$3^{\text {rd }}$ Lince Amalia \\ STIK Muhammadiyah Pontianak \\ Pontianak, Indonesia
}

\begin{abstract}
Background: There are around $\mathbf{3 3}$ million stroke patients around the world. More than 12 million people experience moderate to severe moderate disabilities. Complications caused by stroke are the occurrence of decubitus/pressure ulcer due to immobilization that often occurs in the hips, buttocks, leg joints and heels. Patients who are left in an immobilized state will adversely affect the body's organs. More frequent monitoring needs to be done in patients who are immobilized to minimize the risk of pressure ulcers. Observation results coming from several hospitals yet to show particular/specific intervention towards assisted mobilization for stroke patients. This research is the beginning in the establishment of nursing care model for stroke patient in the intensive care unit for a longterm care that tends to have pressure ulcer complication. Objective: To find out about the description of the implementation of assisted stroke patient mobilization in several Pontianak hospitals in predicting the incidence of pressure ulcer. Methodology: The design of this study is descriptive with a cross sectional approach. Sampling with consecutive sampling. The total nurse respondents in this study were 68 people. The total number of stroke patients in this study were 59 people. The assessment for the observation of assisted mobilization in stroke patients by nurses use Branden Scale for predictive pressure ulcer. The results of the study were analyzed using descriptive statistical data processing. Results: The implementation of assisted mobilization in stroke patients by nurses in several Pontianak hospitals was $100 \%$ well implemented. The predictive value of pressure ulcer in stroke patients using Braden Scale treated in ICU room RSUD Dr. Soedarso most $(86.7 \%)$ were at high risk, room L and HCU RSUD Dr. Soedarso was more than half $(\mathbf{5 3 . 6 \%})$ at moderate risk, and the ICU room at Sultan Syarif Mohamad Alkadrie Hospital, half $(50 \%)$ were at serious risk. Conclusion: The implementation of assisted mobilization in stroke patients by nurses was carried out well in several hospitals in Pontianak. Even though the implementation has not completely carried out according to the procedure. The standard operating procedure also needs a review because of the assisted mobilization model implemented without further assessment towards the occurrence of ulcer pressure.
\end{abstract}

Keywords-component, formatting, style, styling.

\section{INTRODUCTION}

Globally, the second leading cause of death in the world and the sixth most common cause of disability is stroke. About 15 million people suffer from strokes every year, with one third of these cases or around 6.6 million resulting in death [1]. The incidence of stroke in Indonesia based on basic health research (RISKESDAS) in 2007 found cases of 8.3 per 1000 population, and those that had been diagnosed by health workers 6 per 1000 population. The RISKESDAS report in 2013 showed an increase in the incidence of stroke in Indonesia based on the diagnosis of health workers found to be 7 per mile, and those diagnosed with health workers or symptoms were found to be 12.1 per mile [2].

The number of stroke incidences in West Kalimantan according to Riskesdas (2007) ranks 20th with a diagnosis of health care $4.6 \%$, diagnosed by health care or with symptoms of $5.5 \%$. In 2013, according to riskesdas data there was an increase in cases of stroke in West Kalimantan which remained in 20th place with a diagnosis of health finding found to be $5.8 \%$, diagnosed by health workers or with symptoms of $8.2 \%$. Pontianak City Health Department provides data on the number of people suffering from stroke in 2013, amounting to 88 people, in 2014 it increased to 108 people, in 2015 data on the number of people with stroke decreased to 57 people, and experienced an increase in 2016 amounting to 114 people.

Complications that can result from stroke are other health problems in patients such as depression, blood clots in areas that experience paralysis and cause swelling, bruising (pressure sores/ulcer) due to immobilization that often occurs in the hips, buttocks, leg joints and heels, muscles constrict and stiff joints, pneumonia, and shoulder pain[3].

Amir, Halfens, Lohrmann, and Schols (2013) conducted a study on the prevalence of pressure sores and the quality of care in stroke patients in stroke-private hospitals in Indonesia, from 36 respondents found 14 patients had pressure sores or pressure ulcers with category I: 8 patients (57\%), category II: 4 patients (29\%), category III: 2 patients (14\%), and category IV: $0 \%$. The study was conducted using a braden scale on patients at risk, whereas for the actual data through direct observation of the skin suffering from pressure ulcer [4].

Jiang, et al (2014) conducted a study in 12 hospitals in China, from 39,952 patients found 631 patients who suffered from pressure ulcers obtained from the Hospital, with the highest prevalence of the incidence at $>89$ years 
$(2.28 \%)$, the most occurred in intensive care units (ICU) $(4.48 \%)$ [5].

The most important risk factor causing pressure ulcers is immobilization. More frequent monitoring is needed for patients who are immobilized to minimize the risk of developing pressure ulcers. One way to minimize pressure is to schedule a mobilization to change positions and tilt the patient regularly [6].

Based on the problems and results of the study above, researchers are interested in examining "The description of the implementation of assisted mobilization in stroke patients in Pontianak hospitals in predicting the incidence of pressure ulcer".

\section{METHOD}

The study used descriptive explorative design with cross sectional approach. The study was conducted in 3 hospitals in Pontianak, namely ICU room, room L and
HCU Dr. Soedarso, ICU room at Sultan Syarif Mohamad Alkadrie Hospital, ICU room at YARSI Hospital.

This study took sampling by consecutive sampling. The sample used was stroke patients in the period MarchApril 2018 and all nurses who worked in the ICU room, room L and HCU Dr. Soedarso, ICU room at Sultan Syarif Mohamad Alkadrie Hospital, ICU room at YARSI Hospital. The total nurse respondents in this study were 68 people. The total number of stroke patients in this study were 59 people. The statistical analysis used in this study is descriptive / univariate analysis.

\section{RESULT}

A. Data Analysis Result

1) Implementation of assisted mobilization in stroke patients by nurses in ICU Hospital Dr. Soedarso, room L and HCU Dr. Soedarso, as well as the ICU room at Sultan Syarif Mohamad Alkadrie Hospital.

TABEL 1. IMPLEMENTATION OF ASSISTED MOBILIZATION IN STROKE PATIENTS BY NURSES IN ICU HOSPITAL DR. SOEDARSO, ROOM L AND HCU DR. SOEDARSO, AS WELL AS THE ICU ROOM AT SULTAN SYARIF MOHAMAD ALKADRIE HOSPITAL

\begin{tabular}{|c|c|c|c|c|c|c|c|}
\hline & \multirow{3}{*}{ Room Names } & \multicolumn{4}{|c|}{$\begin{array}{l}\text { Implementation of assisted mobilization in } \\
\text { stroke patients by nurses }\end{array}$} & \multicolumn{2}{|c|}{ Total } \\
\hline & & \multicolumn{2}{|c|}{$\begin{array}{l}\text { Performed well if the } \\
\text { total score } \geq 70 \%\end{array}$} & \multicolumn{2}{|c|}{$\begin{array}{c}\text { Not carried out } \\
\text { well if the total } \\
\text { score }<70 \%\end{array}$} & & \\
\hline & & $\mathrm{f}$ & $\%$ & $\mathrm{f}$ & $\%$ & $\mathrm{f}$ & $\%$ \\
\hline 1 & ICU RSUD Dr. Soedarso & 21 & 100 & 0 & 0 & 21 & 100 \\
\hline 2 & L \& HCU RSUD Dr. Soedarso & 20 & 100 & 0 & 0 & 20 & 100 \\
\hline 3 & $\begin{array}{l}\text { ICU RSUD Sultan Syarif Mohamad } \\
\text { Alkadrie }\end{array}$ & 18 & 100 & 0 & 0 & 18 & 100 \\
\hline & Total & 59 & 100 & 0 & 0 & 59 & 100 \\
\hline
\end{tabular}

Tabel 1. showed that the implementation of assisted mobilization in stroke patients by nurses in ICU Dr. Soedarso, room L and HCU Dr. Soedarso, as well as the ICU room at Sultan Syarif Mohamad Alkadrie Hospital $(100 \%)$ were well implemented.

TABEL 2. THE PREDICTED VALUE OF PRESSURE ULCER IN PATIENTS WITH STROKE IN THE ICU HOSPITAL DR. SOEDARSO, ROOM L AND HCU DR. SOEDARSO, AS WELL AS THE ICU ROOM AT SULTAN SYARIF MOHAMAD ALKADRIE HOSPITAL

\begin{tabular}{|c|c|c|c|c|c|c|c|c|c|c|c|}
\hline \multirow{3}{*}{ No } & \multirow{3}{*}{ Room names } & \multicolumn{8}{|c|}{ Prediction of pressure score } & \multirow{2}{*}{\multicolumn{2}{|c|}{ Total }} \\
\hline & & \multicolumn{2}{|c|}{ Mild risk } & \multicolumn{2}{|c|}{$\begin{array}{c}\text { Medium } \\
\text { risk }\end{array}$} & \multicolumn{2}{|c|}{ High Risk } & \multicolumn{2}{|c|}{$\begin{array}{l}\text { Servere } \\
\text { Risk }\end{array}$} & & \\
\hline & & $\mathrm{n}$ & $\%$ & $\mathrm{n}$ & $\%$ & $\mathrm{n}$ & $\%$ & $\mathrm{n}$ & $\%$ & $\mathrm{n}$ & $\%$ \\
\hline 1 & $\begin{array}{l}\text { ICU } \quad \text { RSUD } \\
\text { Dr. Soedarso }\end{array}$ & 0 & 0 & 0 & 0 & 2 & 13,3 & 13 & 86,7 & 15 & 100 \\
\hline 2 & $\begin{array}{l}\text { L \& HCU RSUD } \\
\text { Dr. Soedarso }\end{array}$ & 6 & 21,4 & 15 & 53,6 & 7 & 25 & 0 & 0 & 28 & 100 \\
\hline 3 & $\begin{array}{lr}\text { ICU } & \text { RSUD } \\
\text { Sultan } & \text { Syarif } \\
\text { Mohamad } & \\
\text { Alkadrie } & \end{array}$ & 2 & 12,5 & 0 & 0 & 6 & 37,5 & 8 & 50 & 16 & 100 \\
\hline Total & 8 & 13,6 & 15 & 25,4 & 15 & 25,4 & 21 & 35,6 & 59 & 100 & \\
\hline
\end{tabular}

Tabel 2. shows that the predicted value of pressure ulcer in stroke patients in the ICU Dr. Soedarso most $(86.7 \%)$ had a heavy risk, as well as the predicted value of
2) Prediction of pressure ulcer in stroke patients in ICU Hospital Dr. Soedarso, room L and HCU Dr. Soedarso, as well as the ICU room at Sultan Syarif Mohamad Alkadrie Hospital. 
patients in room L and HCU Dr. Soedarso is more than half $(53.6 \%)$ with moderate risk.

During the March-April 2018 study, no stroke patients were treated in the ICU at Yarsi Hospital, so there was no predicted value of pressure ulcer in stroke patients at Yarsi Hospital. The assessment for the observation of assisted mobilization in stroke patients by nurses in the ICU at Yarsi Hospital was also not possible.

\section{DISCUSSION}

Implementation of assisted mobilization in stroke patients by nurses in several Pontianak hospitals in predicting the incidence of pressure ulcer. Assessment of prediction of pressure ulcer in stroke patients treated by using the Braden Scale is mostly at risk of experiencing severe pressure sores $(86.7 \%)$ in the ICU room of RSUD Dr. Soedarso, and half (50\%) in the ICU room at Sultan Syarif Mohamad Alkadrie Hospital. The prediction results show that the majority of patients at high risk of suffering pressure ulcer are in the ICU Dr. Soedarso and ICU Sultan Syarif Mohamad Alkadrie Regional Hospital. This study is in line with research by Amir, Halfens, Lohrmann and Schols (2013) which shows that the risk of experiencing pressure ulcer is quite frequent in stroke patients treated in stroke-specific hospitals in Indonesia, namely 36 people with pressure injuries included in category I (28\%) and category II (17\%), so the quality of pressure ulcer care in hospitals can be improved in prevention by assisted mobilization, treatment and structural quality indicators[4].

Astutik's research results (2016) states that the most influential risk factors for pressure ulcers are sensory perception, mobility, humidity, nutrition and movement and shifts with a significance level $<0.25$ [7]. The assessment of pressure ulcers prediction in this study shows the majority of patients are at risk of experiencing severe pressure ulcers. The results of the assessment are closely related to the results of interviews which state that there are several rooms where nurses rarely tidy up the folded linen so that it can cause shifts, friction which becomes pressure ulcers in immobilized stroke patients. This shows that there are still risk factors that most influence the patient to experience pressure ulcers. Maryunani (2015) explains the Braden scale observation sheet which assesses 6 parameters namely sensory perception, humidity, activity, mobility, nutrition, friction and shear. Each parameter has 4 categories except friction and shear only 3 categories. Total values are in the range of 4 to 23 [6]. Braden scale is categorized as 15-18 low risk, 13-14 moderate risk, 10-12 high risk, $\leq 9$ severe risk [8].

The research of Widodo, Rosa, and Kurniasari (2017) shows differences in the risk score of pressure ulcers before treatment and after treatment. Provision of measures to reduce the risk of pressure ulcers on the 3rd day, 5th day, and 7 th day is more effective than the 1 st day which obtained a significance value of $p=0,000<0.05$ [9]. It also shows that intensive hospital care requires monitoring of the development of pressure ulcers so that nurses make adequate management of pressure ulcers according to nursing procedures for pressure ulcers. The results of this study differ from the results of interviews with ICU nurses at Sultan Syarif Mohamad Alkadrie Hospital who did not assess the risk of pressure ulcers before changing the position of immobilized stroke patients, only assessing the level of awareness, muscle tone and motor strength.

The results of interviews with nurses who worked in several rooms explained that there were differences in answers in each room in terms of the time of changing the position of immobilized stroke patients, namely in room L and HCU Dr. Soedarso said that the room nurse changed the position of the immobilized patient every 4 hours. This statement is not in accordance with the theory put forward by Rendy and Margareth (2012) that stroke patients who cannot move yet must make changes in body position and extremities to prevent pressure ulcer every 2 hours [10]. The value of pressure ulcer prediction in this study also stated that more than half were at moderate risk $(53.6 \%)$ in the L and HCU rooms of Dr. Soedarso. Benchmark of whether or not the implementation of assisted mobilization in stroke patients by nurses in the room can be seen from several statements of nurses from the interview results. Researchers draw conclusions that wrong actions on nurses can affect the healing process of patients during treatment and can be at risk of experiencing pressure ulcers. Mahendra and Rachmawati (2007) explained that stroke patients in coma or conscious conditions should be mobilized starting 24-48 hours after stroke [3]. The above theory is in line with the results of the research of Usman, Sami, Shakeel, Danish, and Ahmad (2014) which showed that stroke patients who were mobilized earlier $62.4 \%(n=43)$ fully recovered compared to mobilization at the end of $19.4 \%(n=6)$ fully recovered with a p-value $<0.05$, so it can be concluded if patients who were mobilized earlier after a stroke were found to have better recovery. Patients who were mobilized late found no deaths and disabilities, but these patients experienced a longer duration for recovery with disability or with pressure ulcers [11].

Interview results also show differences in explanation from the average nurse in each room studied by answering rarely or sometimes doing massages on the arms, legs and back with moisturizing cream or oil when changing patient positions. Setiadi's research (2017) explains that the ability to change position (ambulation) every 2 hours and skin massage in the limbs and back area in stroke patients can effectively prevent the occurrence of pressure ulcers ( $p$ value $=0,000<0.05$ ) [12]. Andani, Kristiyawati, and Purnomo (2016) also conducted a study that showed that bed rest combined with back massage was more effective in reducing the risk of pressure ulcers in bed rest patients in Ambarawa District Hospital with a $\mathrm{p}$ value $=$ 0.031 ( $\mathrm{p}<0.05)$ [13].

The results of the interview also stated that most nurses change their clothes if they are wet or sweaty which can cause the clothes to become moist. According to Maryunani (2015) measures to prevent pressure ulcers one of which is to clean and dry the skin that is experiencing 
moisture due to incontinence, causing friction and increased shear. ICU patients treated with humidity problems will experience pressure ulcers 4 times more often than patients without humidity problems.[6] The application of these actions by the nurse can minimize the risk of pressure ulcers on the patient. The results of this study are in line with research conducted by Zakiyyah (2014) showing that progressive mobilization I carried out every 2 hours daily can significantly prevent the occurrence of pressure ulcers $(\mathrm{p}=0,000)$ and significantly increase oxygen saturation values in critically installed patients with ventilators $(\mathrm{p}=0,000)[14]$. Early mobilization can be done with the help of nurses. This study explains that the implementation of assisted mobilization in stroke patients by nurses in all rooms studied entirely $(100 \%)$ was carried out well in order to predict the risk of pressure ulcers, but the results of observational assessments of the implementation of assisted mobilization by nurses in this study were only carried out at one time.

\section{CONCLUSIONS}

The implementation of assisted mobilization in stroke patients by nurses was carried out well $(100 \%$ well implemented). The predictive value of pressure ulcer in stroke patients using Braden Scale treated in ICU room RSUD Dr. Soedarso most (86.7\%) were at high risk, room L and HCU RSUD Dr. Soedarso was more than half $(53.6 \%)$ at moderate risk, and the ICU room at Sultan Syarif Mohamad Alkadrie Hospital, half (50\%) were at serious riskEven though the implementation have not completely carried out according to the procedure. The standard operating procedure also needs a review because of the assisted mobilization model implemented without further assessment towards the occurrence of ulcer pressure. The implementation of assisted mobilization in stroke patients by nurses in ICU Hospital Dr. Soedarso, room L and HCU Dr. Soedarso all (100\%) was implemented well. Predicted value of pressure ulcer in stroke patients treated in ICU Hospital Dr. Soedarso by using the Braden Scale which is mostly at risk (86.7\%) and in the L and HCU room Dr. Soedarso more than half $(53.6 \%)$ are at moderate risk. The implementation of assisted mobilization in stroke patients by nurses in the ICU room of Sultan Syarif Mohamad Alkadrie Hospital $(100 \%)$ was carried out well. Predicted value of pressure ulcer in stroke patients treated in ICU Sultan Syarif Mohamad Alkadrie Hospital using half of the Braden Scale $(50 \%)$ is at risk of severe.

\section{ACKNOWLEDGMENT}

We would like to thank to all have assissted in the implementation process until the completion of this research, to the Ministry of Reasearch, Techology and Higher Education of the Indonesian Republic as the funder of this research. We also thank several hospital in Pontianak, West Kalimantan for providing opportunities and assisting us in data collection. Finally, we thank all parties and colleagues at STIK Mugamamdiyah Pontianak, STIKes Aisyiyah Bandung, Sultan Syarief
Mohammad Alkadrie Hospital, Dr. Sudarso General Hospital of Pontianak for their support and motivation.

\section{REFERENCES}

[1] WHO, "Tobacco \& Stroke," WHO, 2017. [Online]. Available: http://www.who.int/tobacco/publications/knowledgesummaries/stroke/en/. [Accessed: 18-Jan-2018].

[2] K. K. R. Indonesia, "Riset Kesehatan Dasar," Kesehatan, Badan Penelitian Dan Pengembangan Ri, Kementerian Kesehatan, 2013. [Online]. Available: https://www.kemkes.go.id/resources/download/general/Hasil Riskesdas 2013.pdf. [Accessed: 29-Oct-2017].

[3] B. Mahendra and E. Rachmawati, Atasi stroke dengan tanaman obat. 2007.

[4] Y. Amir, R. J. G. Halfens, C. Lohrmann, and J. M. G. A. Schols, "Pressure ulcer prevalence and quality of care in stroke patients in an Indonesian hospital," J. Wound Care, vol. 22, no. 5, pp. 254 260, 2013

[5] Q. Jiang et al., "The incidence, risk factors and characteristics of pressure ulcers in hospitalized patients in China," Int. J. Clin. Exp. Pathol., vol. 7, no. 5, p. 2587, 2014.

[6] A. Maryunani, Perawatan luka modern (modern wound care) terkini dan terlengkap. 2015

[7] A. M. Astutik, "Tingkat Resiko Pressure Ulcer Dan Faktor Resikonya Di Rumah Sakit Daerah Tidar Magelang,” Universitas Muhammadyah Yogyakarta, 2016.

[8] P. Plus, "Braden Scale for predicting pressure sore risk." 2018

[9] W. Widodo, E. M. Rosa, and N. Kurniasari, "Pengaruh Tindakan Keperawatan Reduksi Luka Tekan Terhadap Penurunan Risiko Luka Tekan," J. Ilm. Kesehat. Keperawatan, vol. 13, no. 2, 2017.

[10] M. C. Rendy and T. H. Margareth, Asuhan keperawatan medikal bedah dan penyakit dalam. 2012

[11] M. U. Khan, N. Sami, A. S. Khan, S. H. Danish, and F. Ahmad, "To compare the effects of early and late mobilization in post stroke patients," J Med Res, vol. 3, pp. 49-53, 2014.

[12] K. Setiadi, "Analisa Praktik Keperawatan Dengan Intervensi Inovasi Perubahan Posisi Dan Massase Kulit Untuk Mencegah Terjadinya Luka Dekubitus Pada Pasien Stroke Di Ruang Unit Stroke Center Rsud Abdul Wahab Sjahranie Samarinda," Sekolah Tinggi Ilmu Kesehatan Muhammadiyah Samarinda, 2017. [Online]. Available: https://dspace.umkt.ac.id/bitstream/handle/463.2017/366/KARY A ILMIAH AKHIR NERS.pdf?sequence=1\&isAllowed=y. [Accessed: 06-Jul-2018].

[13] M. F. Nurahmandani, S. P. Kristiyawati, and S. E. C. Purnomo, "Efektifitas Alih Baring Dengan Masase Punggung Terhadap Resiko Dekubitus Pada Pasien Tirah Baring Di RSUD Ambarawa," Karya Ilm., 2016.

[14] S. Zakiyyah, "Pengaruh Mobilisasi Progresif Level I: Terhadap Risiko Dekubitus Dan Perubahan Saturasi Oksigen Pada Pasien Kritis Terpasang Ventilator Di Ruang Icu RSUD Dr. Moewardi Surakarta.” Program Pascasarjana Undip, 2014. 